\title{
Soil Fertility and Irrigation Water Characterization of Ziway prison Farm at East Shewa Zone of Oromiya, Ethiopia
}

\author{
Musefa Redi $^{1 *}$, Israel Bekele ${ }^{2}$ \\ ${ }^{1}$ Holeta Agricultural Research Center, Ethiopian Institute of Agricultural Research, Ethiopia \\ ${ }^{2}$ Melkassa Agricultural Research Center, Ethiopian Institute of Agricultural Research, Ethiopia
}

\author{
*Corresponding Author: Musefa Redi, Holeta Agricultural Research Center, Ethiopian Institute of \\ Agricultural Research, Ethiopia
}

\begin{abstract}
Soil fertility and irrigation water quality assessment is useful for the proper fertility management and wise utilization of irrigation water. This study was aimed to characterize the soil fertility status and irrigation water quality for the Ziway Prison farm found in East Shewa Zone of Oromiya, Ethiopia. A total of 11 composite surface soil samples from $0-20 \mathrm{~cm}$ depth and irrigation water samples were collected and analyzed. The results revealed that soils of the farm were loam surface soil texture with an optimum pore

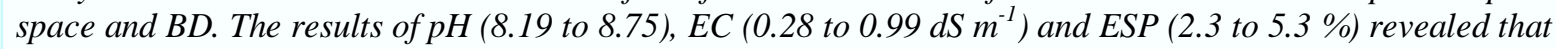
the farm soil was non-saline non-sodic strongly alkaline condition. Total N content of the farm soils (0.109 to $0.202 \%)$ were at moderate to high status, whereas OM contents (1.570 to $2.490 \%)$ were at low status. The contents of available P (4.6 to $\left.16.9 \mathrm{mg} \mathrm{kg}^{-1}\right)$ and CEC (15.0 to $\left.29.8 \mathrm{meq} 100 \mathrm{~g}^{-1}\right)$ were in the range of medium to high. Exchangeable $\mathrm{Ca}, \mathrm{Mg}, \mathrm{K}$ and, extractable Fe and Mn values were at high status. Extractable Cu and $\mathrm{Zn}$ contents were at marginal and low status, respectively. In general, soils of the farm are good in their physico-chemical properties for plant growth but needs OM amendment and application of Zn fertilizer. For an optimum crop production, use of $P$ and $N$ fertilizers is also recommended for the farm Blocks that had medium total $N$ status and available $P$ status less than the critical level $\left(<8 \mathrm{mg} \mathrm{kg}^{-1}\right)$. Moreover, the results of irrigation water $\mathrm{pH}$ (7.67) was at normal status and EC was below $0.75 \mathrm{dSm}^{-1}$, indicating that irrigation water used for the farm qualified as 'safe' for irrigation purpose. However, to prevent the occurrence of sodicity in the long run and sustain productivity of the soil, the Na imbalance in irrigation water should be periodically monitored and appropriate irrigation method need to be used by the farm.
\end{abstract}

Keywords: Soil fertility, Ziway Prison farm, irrigation water quality, physico-chemical properties

\section{INTRODUCTION}

Soil is an important natural resource for agriculture that is the basic economic source of Ethiopia. Declining of soil fertility has been identified as one of the most important constraints to limit food production in Ethiopia (FAO, 2002). The low soil fertility has been attributed to low inherent soil fertility, loss of nutrients through erosion, acidity, nutrient depletion, lack of soil fertility replenishment, nutrient mining, lack of balanced fertilization (Hurni and Bruno (1990); Tesfahunegn et al. (2011); and Wondwosen and Sheleme (2011)), improper irrigation practices and intensive mechanized farming (Wakene and Heluf 2003). Moreover, poor irrigation agriculture in arid and semi-arid regions also results in declining of soil fertility through soil salinity/sodicity development.

Productivity of agricultural lands majorly depends upon availability of plant nutrients in the soil and soil moisture status. Hence, the presence of essential plant nutrients both in adequate and available forms in the soil and availability of soil moisture to plants were among the most detrimental factors of crop production and productivity in the agriculture sector. In general, the suitability of soil for crop production depends on its fertility level, which is evaluated based on the soil physico-chemical properties. For this reason, recent interest in evaluating the fertility status of soils has been inspired in Ethiopia (Wakene and Heluf, 2003).

In the area under study, soil fertility problems relate with inappropriate irrigation practice, removal of crop residues and continuous cultivation. As a result, the status of the soil and irrigation water should be evaluated and known for appropriate land use and water management (Al-Ghobari, 2011). Furthermore, knowledge of the chemical composition and quality of water sources are of particular 
significance for the proper management and wise utilization of irrigation water. However, limited information is available on the characteristics of soil physico-chemical and irrigation water quality particularly in the study area that could be useful in the management and use of the soils on a sustainable manner. Therefore, this study was aimed to characterize the soil fertility status and irrigation water quality for the Ziway Prison farm.

\section{MATERIALS AND MeTHODS}

\subsection{Site Description}

Ziway Prison farm located at Ziway town in Adami Tullu JidoK ombolcha District of East Shewa Zone in Oromiya Regional state of Ethiopia, which is about $160 \mathrm{~km}$ South of Addis Ababa. As the area is in the Great Rift Valley, it is determined/ characterized by a semi-arid and arid climate and, thus, crop production mainly depends on irrigation. Its average annual precipitation is about $700 \mathrm{~mm}$ of which $42 \%$ falls in the period June to September (OESPO, 2003). The driest months are November and December. The mean annual temperature is $20^{\circ} \mathrm{C}$ at Ziway and AdamiTullu station (OESPO, 2003). The altitude of the farm varies from about 1621 to 1650 meter above sea level (masl) having a uniform topography i.e. feature with a gentle slope (3 to 5\%).

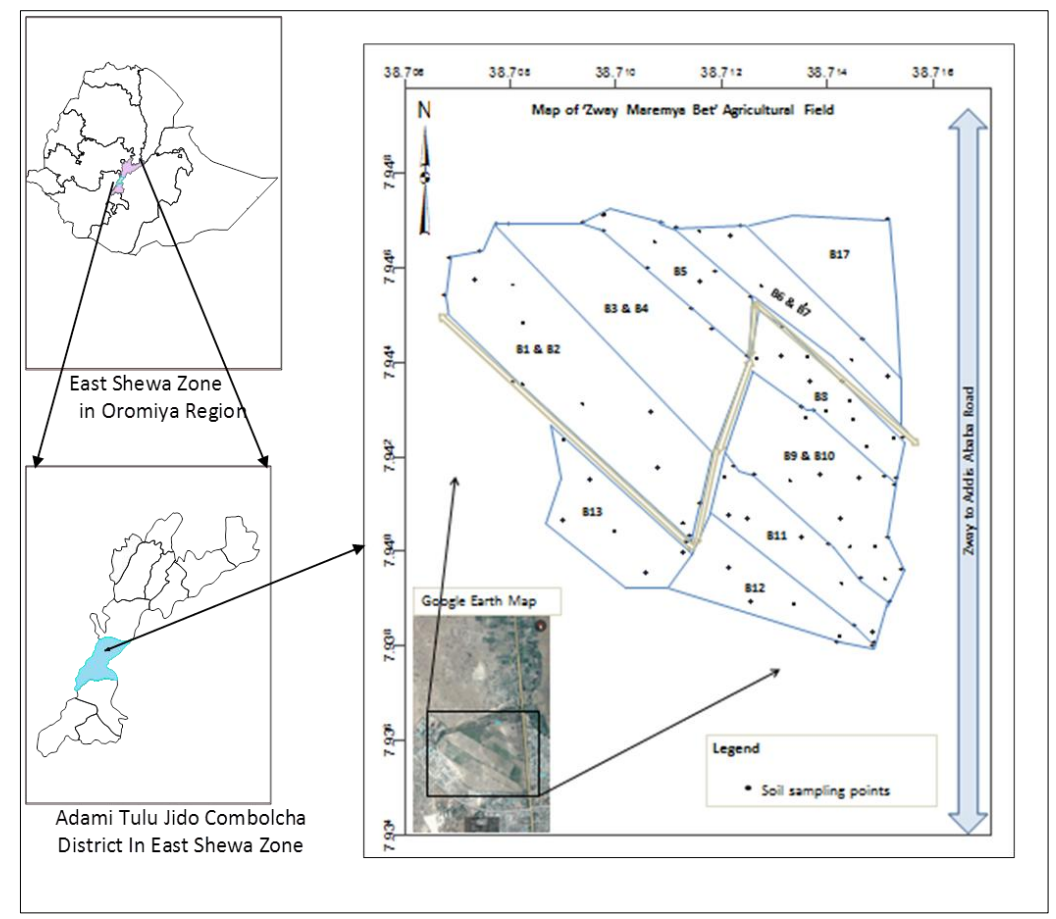

Figure1. Location Map of Ziway Prison Agricultural Farm in East Shewa Zone, Ethiopia

\subsection{Soil and Irrigation Water Sampling}

Detail observation of the farm land was made during site survey. According to the information obtained from the farm manager, the total area of the farm is about 71 hectares and most part of it has been under continuous cultivation with different crops. Based on topographic gradient, cropping history and using the farm's Block division, the field was divided into different Blocks (Block 1 to Block 13 and Block 17). Then, representative composite surface soil samples from $0-20 \mathrm{~cm}$ depth were collected from each Block with an appropriate number of sub samples. In some cases (Block 8, 9 and 10), more than one composite soil samples were collected, considering the perennial crop types existing in the field during sampling time. Accordingly, a total of 11 composite soil samples were collected before the start of main cropping season of 2017. On the other hand, soil sample was not collected from Block 17, as the field was completely covered by maize and vegetable crops and treated with fertilizers. Separate core samples were also taken from each Block for the determination of soil bulk density. In addition, two liters irrigation water sample was collected using labeled and clean polyethylene bottle from the source for the determination of its quality of irrigation water. Geographic positioning system (GPS) coordinates of each sub-sampling spots in a Block were recorded and geo-spatial reference of those points was mapped using Arc Map-10.0 software (Figure 1). 


\subsection{Soil and Water Sample Preparation and Laboratory Analysis}

The soil samples collected were air dried, crushed and passed through a $2 \mathrm{~mm}$ sieve for the analysis of selected soil physico-chemical properties following standard procedure. The water sample was transported immediately and kept in the Ice box to keep the in situ condition of the irrigation water until analysis. But, some sensitive parameters like $\mathrm{pH}$ and electrical conductivity were immediately analyzed to prevent biological transformation. All analysis was carried out at the accredited Soil and Plant Analysis Laboratory of Holeta Agricultural Research Center.

Soil particle size distribution was analyzed by the hydrometer method (Bouyoucos, 1962) and textural class names were determined following the textural triangle of USDA system as described by Rowell (1994). Soil bulk density was determined by the undisturbed core sampling method after drying the soil samples in an oven at $105{ }^{\circ} \mathrm{C}$ to constant weights, while particle density was determined by the pycnometer method (Blake, 1965). Percentage pore space was computed from the values of bulk density (BD) and particle density (PD) (Brady and Weil, 2002) as: Total porosity $(\%)=(1-\mathrm{BD} / \mathrm{PD}) \mathrm{x}$ 100

Potentiometric method using a glass-calomel combination electrode was used to measure $\mathrm{pH}$ of the soils in water suspension in a 1:2.5 (soil: liquid ratio) (Van Reeuwijk, 1992). Electrical conductivity (EC) was measured using a conductivity meter from soil to water suspension of 1:2.5. The Walkley and Black (1934) wet digestion method was used to determine soil organic carbon (OC) content. Percent soil organic matter $(\mathrm{OM})$ was obtained by multiplying percent soil $\mathrm{OC}$ by a factor of 1.724 ; following the assumptions that OM is composed of 58\% OC. Total $\mathrm{N}$ was analyzed using the Kjeldahl method as described by Blake (1965). Available $\mathrm{P}$ was determined using the standard Olsen et al. (1954) extraction method. As described by Sahlemedhin and Taye (2000), $\mathrm{CaCO}_{3}$ content was determined using calcimeter method and extractable micronutrients $(\mathrm{Fe}, \mathrm{Cu}, \mathrm{Zn}$ and $\mathrm{Mn}$ ) were extracted by DTPA and measured by using atomic absorption spectrophotometer (AAS) instrument.

Exchangeable cations ( $\mathrm{Ca}, \mathrm{Mg}, \mathrm{K}$ and $\mathrm{Na}$ ) were determined after extracting the soil samples by $1 \mathrm{~N}$ ammonium acetate at $\mathrm{pH}$ 7.0. The cations in the extract were measured by AAS (Rowell, 1994). Then, Cation exchange capacity (CEC) was determined from the same soil that was leached with ammonium acetate through distillation and titration of ammonia, after washing down of excess ammonium acetate by ethyl alcohol as described by Sahlemedhin and Taye (2000). Exchangeable sodium percentage (ESP) was computed using the formula: ESP $(\%)=[$ exchangeable sodium $\left.\left(\mathrm{Na}^{+}\right) / \mathrm{CEC}\right] \times 100$.

\subsection{Irrigation Water Quality Analysis}

Irrigation water used by the farm was tested for different quality parameters, such as $\mathrm{pH}$, EC, soluble cations (Ca, Mg, K and $\mathrm{Na}$ ) following standard procedures (Franson, 1981). Sodium adsorption ratio (SAR) was calculated from the concentrations of soluble $\mathrm{Na}, \mathrm{Ca}$ and $\mathrm{Mg}$ as suggested by Ayers and Westcot (1994) as follows: $\mathrm{SA} R=\frac{\mathrm{Na}^{+}}{\sqrt{\frac{\mathrm{Ca}^{2+}+\mathrm{Mg}^{2+}}{2}}}$

\subsection{Statistical Analysis}

The soil and water analytical data were subjected to descriptive statistics. The results were interpreted as very low, low, medium, high and very high using standard ratings.

\section{RESULTS AND DISCUSSION}

\subsection{Soil Physical Properties}

\subsubsection{Soil texture}

The soils of the farm were loam surface soil texture with mean sand, silt and clay percentages of 45.8 , 32.1 and $22.4 \%$, respectively (Table 1). A loam soil texture is the most preferred soil for crop production especially in irrigated agriculture to facilitate better infiltration. Moreover, a loam soil texture is an indication of its workability, good drainage and aeration, and maximum root development and microbial activity. Some previous works have also revealed that soil texture 
Soil Fertility and Irrigation Water Characterization of Ziway prison Farm at East Shewa Zone of Oromiya, Ethiopia

determines a number of physical and chemical properties of soils. It affects the infiltration and retention of water, soil aeration, absorption of nutrients, microbial activities, tillage and irrigation practices (Gupta, 2004).

\subsubsection{Bulk density, particle density and total porosity}

The lowest bulk density (BD) $\left(1.08 \mathrm{~g} \mathrm{~cm}^{-3}\right)$ and the highest total porosity (55.6\%) were recorded under soils of B5, while samples from B8 planted with onion exhibited the highest BD $\left(1.38 \mathrm{~g} \mathrm{~cm}^{-3}\right)$ and lowest total porosity (43.8\%) (Table 1), indicating that soils of B5 has relatively good physical property as compared to soils of the other Blocks. This could be due to limited mechanized tillage practice, as the field has been used for wine production for longer period. The highest BD recorded under soils of B8 planted with onion could be due to compaction of the soil surface where macropores are closed first by the mechanical impact (Zhang et al., 2000). Motavalli and McConnell (1998) also reported increase in $\mathrm{BD}$ due to continuous cultivation with mechanized tillage for several years. In general, porosity and BD values of the farm soils were said to be relatively under an optimum range for agricultural uses (Bohn et al., 2001). Normal range of BD and porosity indicates the existence of loose soil condition, not too compacted to limit root penetration, and restrict air and water movement (Bohn et al., 2001).

Table1. Selected soil physical properties of Ziway Prison farm, 2017.

\begin{tabular}{|c|c|c|c|c|c|c|c|}
\hline \multirow[b]{2}{*}{ Block No. } & \multicolumn{4}{|c|}{ Particle size Distribution } & \multirow{2}{*}{$\begin{array}{l}\text { BD }^{*} \\
\left(\mathrm{~g} \mathrm{~cm}_{3}^{-}\right.\end{array}$} & \multirow{2}{*}{$\begin{array}{c}\text { PD }^{*} \\
\left(\begin{array}{c}\mathrm{g} \mathrm{cm}^{-} \\
\left.{ }^{-}\right)\end{array}\right.\end{array}$} & \multirow{2}{*}{$\begin{array}{c}\text { Porosity } \\
(\%)\end{array}$} \\
\hline & $\begin{array}{c}\text { Clay } \\
(\%)\end{array}$ & $\begin{array}{l}\text { Silt } \\
(\%)\end{array}$ & $\begin{array}{c}\text { Sand } \\
(\%)\end{array}$ & Texture & & & \\
\hline $\mathrm{B} 1$ and B2 & 25.0 & 33.8 & 41.3 & loam & 1.31 & 2.42 & 45.8 \\
\hline B3 and B4 & 42.5 & 3.8 & 53.8 & sandy clay & 1.31 & 2.37 & 44.8 \\
\hline B5 & 20.0 & 26.3 & 53.8 & sandy loam & 1.08 & 2.44 & 55.6 \\
\hline B6 and B7 & 15.0 & 38.8 & 46.3 & loam & 1.30 & 2.41 & 46.2 \\
\hline B8 (Banana ) & 21.3 & 37.5 & 41.3 & loam & 1.11 & 2.26 & 51.0 \\
\hline B8 (Onion) & 20.0 & 31.3 & 48.8 & loam & 1.38 & 2.45 & 43.8 \\
\hline B9 and B10 (Mango \& Avocado) & 22.5 & 36.3 & 41.3 & loam & 1.23 & 2.45 & 50.0 \\
\hline B9 and B10 (Papaya) & 15.0 & 36.8 & 51.3 & loam & 1.23 & 2.51 & 51.1 \\
\hline B11 & 12.5 & 33.8 & 53.8 & sandy loam & 1.27 & 2.47 & 48.7 \\
\hline B12 & 25.0 & 33.8 & 41.3 & loam & 1.36 & 2.46 & 44.9 \\
\hline B13 & 27.5 & 41.3 & 31.3 & clay loam & 1.09 & 2.39 & 54.3 \\
\hline Mean & 22.4 & 32.1 & 45.8 & loam & 1.24 & 2.42 & 48.7 \\
\hline Min & 12.5 & 3.8 & 31.3 & & 1.08 & 2.26 & 43.8 \\
\hline Max & 42.5 & 41.3 & 53.8 & & 1.38 & 2.51 & 55.6 \\
\hline
\end{tabular}

*BD = Bulk Density; $P D=$ Particle Density

\subsection{Soil Chemical Properties}

\subsubsection{Soil $p H$ and Electrical Conductivity}

The $\mathrm{pH}$ values of soils in the farm ranged between 8.19 and 8.75 , which showed a strongly alkaline condition (Tekalign, 1991). While, the electrical conductivity (EC) ranged from 0.28 to $0.99 \mathrm{dS} \mathrm{m}^{-1}$ which was far below $4 \mathrm{dS} \mathrm{m}^{-1}$ (Table 2) and exchangeable sodium percentage (ESP) was also far below 15 (Table 3), indicating that the farm soil was non-saline non-sodic condition. Furthermore, the results of $\mathrm{pH}, \mathrm{EC}$ and ESP revealed that the farm soil was strongly alkaline, but salinity and sodicity problem at this particular time does not exist. Strong alkalinity of the farm soil could be due to the limited mean annual rainfall $(700 \mathrm{~mm})$ that the area receives to leach away base forming cations from the surface soils.

\subsubsection{Soil organic matter, total nitrogen and $C: N$ ratio}

The values of total $\mathrm{N}$, organic matter $(\mathrm{OM})$ and $\mathrm{C}$ : $\mathrm{N}$ ratios of the soils in each Block of the farm are presented in Table 2. Total $\mathrm{N}$ content of the soils ranged between $0.109 \%$ in $\mathrm{B} 8$ planted with onion and $0.202 \%$ in B1 and B2 (Table 2), indicating that the soils were moderate $(0.05-0.12 \%)$ to high $(0.12-0.25 \%)$ in total $\mathrm{N}$ status (Tekalign, 1991). While the OM content ranged from $1.570 \%$ in soils 
Soil Fertility and Irrigation Water Characterization of Ziway prison Farm at East Shewa Zone of Oromiya, Ethiopia

of B12 to $2.490 \%$ in B1 and B2. According to standards given by Tekalign (1991), the status of OM was low. The low OM content of the farm soils could be due to low amount of organic materials applied to the soil and complete removal of the biomass from the field (Yihenew, 2002). In addition, the practice of the farm in cultivating legume crops as an intercrop and crop rotation system was poor and, thus, contributed to the low status of OM. Therefore, in order to increase the OM and total $\mathrm{N}$ contents of the soils, introduction of leguminous species into the cropping system has to be exercised in the farm. The benefits of legume crops have been reported by Singh et al. (2002), and Nnadi and Haque (1988). Furthermore, as OM is the main supplier of soil N, low OM content of the farm soils would likely to limit the soils productivity and, thus, require $\mathrm{N}$ fertilization especially Blocks that had medium total N status (B3, B4, B5, B8 (Onion), B9 and B10 (Papaya), and B11).

The values of $\mathrm{C}$ : $\mathrm{N}$ ratio ranged from 7.1 to 12.6 (Table 2), indicating that the ratio was under the favorable range (10-15) for cropping lands (Taylor et al., 2010) with a good rate decomposition and mineralization of OM. Moreover, immobilization of inorganic $\mathrm{N}$ might not be a concern for the farm (Mohammad et al., 2011).

Table2. Selected soil chemical properties of Ziway Prison farm, 2017.

\begin{tabular}{|c|c|c|c|c|c|c|}
\hline Block No. & $\mathbf{p H}\left(\mathrm{H}_{2} \mathrm{O}\right)$ & $\begin{array}{c}E C * \\
\left(d S ~ m^{-1}\right)\end{array}$ & Total N (\%) & $\begin{array}{l}\text { C:N* } \\
\text { Ratio }\end{array}$ & OM* $(\%)$ & Olsen P (mg kg $\left.{ }^{-1}\right)$ \\
\hline $\mathrm{B} 1$ and $\mathrm{B} 2$ & 8.37 & 0.99 & 0.202 & 7.2 & 2.490 & 9.0 \\
\hline $\mathrm{B} 3$ and B4 & 8.19 & 0.68 & 0.116 & 8.7 & 1.750 & 13.3 \\
\hline B5 & 8.46 & 0.28 & 0.111 & 9.5 & 1.820 & 9.3 \\
\hline B6 and B7 & 8.43 & 0.43 & 0.125 & 7.8 & 1.690 & 12.4 \\
\hline B8 (Banana ) & 8.75 & 0.35 & 0.127 & 7.8 & 1.710 & 7.5 \\
\hline B8 (Onion) & 8.57 & 0.39 & 0.109 & 12.6 & 2.370 & 13.6 \\
\hline $\begin{array}{c}\text { B9 and B10 (Mango } \\
\text { \&Avocado) }\end{array}$ & 8.46 & 0.28 & 0.129 & 8.7 & 1.930 & 4.6 \\
\hline B9 and B10 (Papaya) & 8.70 & 0.32 & 0.112 & 8.6 & 1.660 & 4.9 \\
\hline B11 & 8.19 & 0.74 & 0.110 & 10.7 & 2.030 & 16.9 \\
\hline B12 & 8.34 & 0.48 & 0.127 & 7.2 & 1.570 & 12.2 \\
\hline B13 & 8.39 & 0.86 & 0.200 & 7.1 & 2.450 & 12.6 \\
\hline Mean & 8.44 & 0.53 & $\mathbf{0 . 1 3 3}$ & 8.7 & 1.952 & 10.6 \\
\hline Min & 8.19 & 0.28 & 0.109 & 7.1 & 1.570 & 4.6 \\
\hline Max & 8.75 & 0.99 & 0.202 & 12.6 & 2.490 & 16.9 \\
\hline
\end{tabular}

$*_{E C}=$ electrical conductivity; $C: N$ ratio = Carbon to Nitrogen ratio; OM = Organic Matter; $d S m^{-1}=$ deciSiemens per meter

\subsubsection{Available Phosphorus}

The contents of available P extracted by the Olsen et al. (1954) method varied from 4.6 to $16.9 \mathrm{mg} \mathrm{kg}$ 1. The lowest value was recorded in B9 and B10 planted with mango, whereas the highest was obtained in B11 (Table 2). According to Olsen et al. (1954), available P content of soils between 5- 10 and greater than $10 \mathrm{mg} \mathrm{kg}^{-1}$ are said to be medium and high, respectively. Thus, B3, B4, B6, B7, B11, B12, B13 and B8 planted with onion soils had high available P status, whereas soils of the rest Blocks had medium status. Moreover, Musefa et al. (2016), Tekalign and Haque (1991), and Finck and Vendateswarlu (1982) reported that the critical level of Olsen P values to be $8 \mathrm{mg} \mathrm{kg}^{-1}$ for some crops on major agriculturally important soils of Ethiopia. This implying that the farm Blocks such as B8 planted with Banana and B9 and B10 planted with Mango, Avocado and Papaya had available P status less than the critical level $\left(<8 \mathrm{mg} \mathrm{kg}^{-1}\right)$ and, thus, would most likely respond to $\mathrm{P}$ fertilization.

\subsubsection{Cation exchange capacity}

The cation exchange capacity (CEC) ranged from 15.0 meq $100 \mathrm{~g}^{-1}$ in soils of B6 and B7 to 29.8 meq $100 \mathrm{~g}^{-1}$ in B13 (Table 3). According to Landon (1991), the CEC of B1, B2 and B13 soils falls under the range of high ( 25 to 40 meq $100 \mathrm{~g}^{-1}$ ), whereas the rest Blocks had moderate (15 to 25 meq $100 \mathrm{~g}^{-1}$ ) CEC status. The reason for higher CEC of B1, B2 and B13 soils could be due to relatively higher content of OM. In addition, the higher clay content and clay loam texture in B13 also contributed to the higher value of CEC. While medium CEC status in soils of the rest Blocks could be attributed to lower content of clay and OM. Generally, the CEC of soils varies with its texture and OM contents. 
Soil Fertility and Irrigation Water Characterization of Ziway prison Farm at East Shewa Zone of Oromiya, Ethiopia

Thus, sandy soils had lower CEC values than clayey soils because the coarse-textured soils are commonly lower in both clay and humus that are electrically charged (usually negatively) and these attract positively charged ions in the soil solution (Brady and Weil, 2002). Therefore, improving the OM contents of Blocks having medium CEC status would improve their CEC values.

Table3. Selected soil chemical properties of Ziway Prison farm, 2017.

\begin{tabular}{|c|c|c|c|c|c|c|c|}
\hline \multirow[t]{2}{*}{ Block No. } & \multirow[t]{2}{*}{$\begin{array}{c}\text { CEC * } \\
\left(\operatorname{meq} 100 g^{-1}\right)\end{array}$} & \multicolumn{4}{|c|}{$\begin{array}{l}\text { Exchangeable cations } \\
\left(\mathrm{meq}^{\left.100 \mathrm{~g}^{-1}\right)}\right.\end{array}$} & \multirow{2}{*}{$\begin{array}{c}\text { ESP* } \\
(\%)\end{array}$} & \multirow{2}{*}{$\begin{array}{c}\mathrm{CaCO}_{3} \\
(\%)\end{array}$} \\
\hline & & $\mathbf{K}$ & $\mathbf{N a}$ & Mg & $\mathbf{C a}$ & & \\
\hline $\mathrm{B} 1$ and $\mathrm{B} 2$ & 25.1 & 3.25 & 1.32 & 10.1 & 82.9 & 5.3 & 3.69 \\
\hline $\mathrm{B} 3$ and B4 & 20.7 & 2.29 & 0.52 & 9.1 & 64.0 & 2.5 & 1.32 \\
\hline B5 & 16.0 & 1.82 & 0.45 & 9.2 & 49.8 & 2.8 & 0.48 \\
\hline B6 and B7 & 15.0 & 1.59 & 0.65 & 5.8 & 47.3 & 4.4 & 1.28 \\
\hline B8 (Banana ) & 19.6 & 2.39 & 0.76 & 10.4 & 90.2 & 3.9 & 5.27 \\
\hline B8 (Onion) & 17.7 & 1.96 & 0.80 & 8.1 & 46.2 & 4.5 & 0.21 \\
\hline B9 and B10 (Mango and Avocado) & 17.8 & 1.79 & 0.54 & 9.4 & 50.5 & 3.1 & 0.51 \\
\hline B9 and B10 (Papaya) & 15.6 & 1.62 & 0.63 & 5.8 & 50.1 & 4.1 & 0.38 \\
\hline B11 & 16.3 & 1.75 & 0.45 & 6.7 & 60.7 & 2.7 & 0.95 \\
\hline B12 & 27.0 & 2.20 & 0.62 & 8.3 & 68.5 & 2.3 & 0.85 \\
\hline B13 & 29.8 & 2.83 & 1.07 & 9.3 & 86.8 & 3.6 & 3.34 \\
\hline Mean & 20.1 & 2.14 & 0.71 & 8.4 & 63.3 & 3.6 & 1.66 \\
\hline Min & 15.0 & 1.59 & 0.45 & \begin{tabular}{|l|l|}
5.8 \\
\end{tabular} & 46.2 & 2.3 & 0.21 \\
\hline Max & 29.8 & 3.25 & 1.32 & 10.4 & 90.2 & 5.3 & 5.27 \\
\hline
\end{tabular}

$* C E C=$ cation exchange capacity, ESP = exchangeable sodium percentage, meq $100 g^{-1}=$ miliequivalent per 100 gram of soil

\subsubsection{Exchangeable cations ( $\mathrm{Ca}, \mathrm{Mg}, \mathrm{K}$ and $\mathrm{Na}$ )}

Exchangeable K ranged from 1.59 to 3.25 meq $100 \mathrm{~g}^{-1}$; Na from 0.45 to $1.32 \mathrm{meq} 100 \mathrm{~g}^{-1}$; $\mathrm{Mg}$ from 5.8 to 10.4 meq $100 \mathrm{~g}^{-1}$ and Cafrom 46.2 to $90.2 \mathrm{meq} 100 \mathrm{~g}^{-1}$ (Table 3). According to standard given by FAO (2006a), the status of exchangeable $\mathrm{Ca}$ and $\mathrm{Mg}$ were categorized as high, indicating the presence of sufficient $\mathrm{Ca}$ and $\mathrm{Mg}$ in the soils of the farm. Moreover, in Ethiopian soils, exchangeable $\mathrm{Ca}$ and $\mathrm{Mg}$ cations dominate the exchange sites of most soils and excessive or deficient amounts are uncommon (Mesfin, 1998). Exchangeable K status of the farm soils were above $1.2 \mathrm{meq} 100 \mathrm{~g}^{-1}$ and rated as high (Landon, 1991). As a result a response to $\mathrm{K}$ fertilizer is unlikely. On the other hand, exchangeable $\mathrm{Na}$ was categorized as medium to high (FAO, 2006a), but the exchangeable sodium percentage (ESP) varied from 2.3 to $5.3 \%$ (Table 3), indicating that serious Na toxicity problem on crops and/or adverse effect on soil physical properties are unlikely to occur, as the values of ESP were under the acceptable level (ESP < 10) for plant growth (Silva and Uchida, 2000). However, care should be taken not to increase the exchangeable $\mathrm{Na}$ level due to inappropriate irrigation practice. When $\mathrm{Na}$ is found in appreciable amounts, it alters the soil physical and chemical properties mainly by inducing swelling and dispersion of clay and organic particles, resulting in restricting water permeability and air movement, formation of crust and decrease solubility and availability of $\mathrm{Ca}$ and Mg ions (Brady and Weil, 2002).

In general, magnitude of cations in the farm soils was in the order of $\mathrm{Ca}>\mathrm{Mg}>\mathrm{K}>\mathrm{Na}$ which indicates that the farm soils were inherently highly productive, as the exchange complex was dominated by $\mathrm{Ca}$ and $\mathrm{Mg}$ as compared to $\mathrm{k}$ and $\mathrm{Na}$ (FAO, 1979). Moreover, the presence of high amounts of $\mathrm{Ca}$ as compared to $\mathrm{Mg}, \mathrm{K}$ and $\mathrm{Na}$ could be due the nature of parent material, high evapotranspiration and practicing of irrigation that would leave high amounts of $\mathrm{Ca}$ in the surface soil. Such situations often cause the total exchangeable cations to exceed the CEC of soils.

\subsubsection{Calcium carbonate $\left(\mathrm{CaCO}_{3}\right)$}

The farm soils $\mathrm{CaCO}_{3}$ ranged from 0.21 to $5.27 \%$ (Table 3). The result revealed that the amount of $\mathrm{CaCO}_{3}$ was not in a problematic amount and hard pan formation due to $\mathrm{CaCO}_{3}$ accumulation at lower depth was not expected (FAO, 2006). 
Soil Fertility and Irrigation Water Characterization of Ziway prison Farm at East Shewa Zone of Oromiya, Ethiopia

\subsubsection{Extractable micronutrients ( $\mathrm{Zn}, \mathrm{Fe}, \mathrm{Mn}$ and $\mathrm{Cu}$ )}

The results of extractable micronutrients ( $\mathrm{Fe}, \mathrm{Mn}, \mathrm{Cu}$ and $\mathrm{Zn}$ ) for soils of all Blocks are presented in Table 4. According to the criteria developed by Jones (2003), the concentrations of extractable Fe (5.21 to $13.71 \mathrm{mg} \mathrm{kg}^{-1}$ ) and $\mathrm{Mn}\left(4.07\right.$ to $8.31 \mathrm{mg} \mathrm{kg}^{-1}$ ) were generally adequate across all Blocks of the farm. However, the concentrations of $\mathrm{Zn}\left(0.19\right.$ to $\left.0.44 \mathrm{mg} \mathrm{kg}^{-1}\right)$ and $\mathrm{Cu}\left(0.14\right.$ to $\left.0.43 \mathrm{mg} \mathrm{kg}^{-1}\right)$ were at low and marginal status, respectively (Table 4). In line with this, the critical level of DTPA extractable $\mathrm{Cu}$ (Sims and Johnson, 1991) and the deficiency level of Zn (Jones, 2003) in soils are 0.1 to $2.5 \mathrm{mg} \mathrm{kg}^{-1}$ and 0.5 to $1.0 \mathrm{mg} \mathrm{kg}^{-1}$, respectively. Therefore, extractable $\mathrm{Cu}$ status was within the critical limit for crop production, whereas all farm Blocks soils were deficient in $\mathrm{Zn}$ (far below $0.5 \mathrm{mg}$ $\mathrm{kg}^{-1}$ ) for most of the crop plants. Thus, recommended rate of $\mathrm{Zn}$ fertilizer or any management practice that could boost the farm soil $\mathrm{Zn}$ status should be exercised for optimum crop production.

Table4. Extractable micronutrients status of Ziway Prison farm, 2017.

\begin{tabular}{|c|c|c|c|c|}
\hline \multirow{2}{*}{ Block No. } & \multicolumn{3}{|c|}{ Extractable micronutrients $\left(\mathbf{m g ~ k g}^{-1}\right)$} \\
\cline { 2 - 4 } & $\mathbf{Z n}$ & $\mathbf{F e}$ & $\mathbf{M n}$ & $\mathbf{C u}$ \\
\hline B1 and B2 & 0.25 & 5.21 & 7.77 & 0.26 \\
\hline B3and B4 & 0.22 & 6.74 & 8.31 & 0.25 \\
\hline B5 & 0.29 & 7.04 & 5.50 & 0.43 \\
\hline B6 and B7 & 0.39 & 9.13 & 6.56 & 0.36 \\
\hline B8 (Banana ) & 0.24 & 7.47 & 4.09 & 0.27 \\
\hline B8 (Onion) & 0.44 & 8.64 & 5.68 & 0.20 \\
\hline B9 and B10 (Mango and Avocado) & 0.29 & 13.71 & 5.58 & 0.22 \\
\hline B9 and B10 (Papaya) & 0.28 & 9.53 & 4.07 & 0.34 \\
\hline B11 & 0.26 & 7.03 & 5.44 & 0.14 \\
\hline B12 & 0.31 & 7.10 & 5.56 & 0.17 \\
\hline B13 & 0.19 & 6.11 & 6.88 & 0.31 \\
\hline Mean & $\mathbf{0 . 2 9}$ & $\mathbf{7 . 9 7}$ & $\mathbf{5 . 9 5}$ & $\mathbf{0 . 2 7}$ \\
\hline Min & $\mathbf{0 . 1 9}$ & $\mathbf{5 . 2 1}$ & $\mathbf{4 . 0 7}$ & $\mathbf{0 . 1 4}$ \\
\hline Max & $\mathbf{0 . 4 4}$ & $\mathbf{1 3 . 7 1}$ & $\mathbf{8 . 3 1}$ & $\mathbf{0 . 4 3}$ \\
\hline
\end{tabular}

\subsection{Irrigation Water Quality}

As shown in Table 5, it was observed that the irrigation water qualify for normal $\mathrm{pH}$ range as the $\mathrm{pH}$ value was under the range of 6.5 to 8.4 (Ayers and Westcot, 1994). In line with this, EC of the water was below $0.75 \mathrm{dS} \mathrm{m}^{-1}$, indicating that the water was free from salinity hazard (Bauder et al., 2014). However, the irrigation water contains high sodium $\left(2.48 \mathrm{meq} \mathrm{L}^{-1}\right)$ as compared to Ca $\left(0.98 \mathrm{meq} \mathrm{L}^{-1}\right)$ and $\mathrm{Mg}\left(0.91 \mathrm{meq}^{-1}\right)$ contents, indicating soil sodicity problem might be a potential (Ayers and Westcot, 1994) that could causes swelling and dispersion of soil clays and result to obstruction of infiltration. Accroding to Ayers and Westcot (1994) guideline for assessment of $\mathrm{Na}$ hazard of irrigation water based on SAR (assesses the potential for water infiltration problem due to a $\mathrm{Na}$ imbalance in irrigation water) and EC (at the same Na content, the swelling potential of low salinity (EC) water is greater than high EC water), the irrigation water used by the farm could not be a potential for water infiltration problem as its EC $\left(0.2\right.$ to $\left.0.7 \mathrm{dS} \mathrm{m}^{-1}\right)$ and SAR (0 to 3) values were under normal range for irrigation purpose.

Table5. Some chemical characteristics of irrigation water used by Ziway Prison farm, 2017.

\begin{tabular}{|c|c|c|c|c|c|c|c|}
\hline Sample type & $\mathrm{pH}$ & $\begin{array}{c}\mathrm{EC} \\
\left(\mathrm{dS} \mathrm{m}^{-1}\right)^{*}\end{array}$ & $\begin{array}{c}\mathrm{Ca} \\
\left(\mathrm{meq} \mathrm{L}^{-1}\right)^{*}\end{array}$ & $\begin{array}{c}\mathrm{Mg} \\
\left(\mathrm{meq} \mathrm{L}^{-1}\right)\end{array}$ & $\begin{array}{c}\mathrm{K} \\
\left(\mathrm{meq} \mathrm{L}^{-1}\right)\end{array}$ & $\begin{array}{c}\mathrm{Na} \\
\left(\mathrm{meq} \mathrm{L}^{-1}\right)\end{array}$ & $\mathrm{SAR}^{*}$ \\
\hline Irrigation Water & 7.67 & 0.65 & 0.98 & 0.91 & 0.27 & 2.48 & 2.55 \\
\hline
\end{tabular}

* SAR= Sodium Absorption Ratio; $d S \mathrm{~m}^{-1}=$ deciSiemens per meter; meq $L^{-1}=$ miliequivalent per liter

Furthermore, reduced infiltration from application of water with high Na content might not be serious problem for the farm due to its loam soil texture with mean clay fraction below $30 \%$ (Bauder et al., 2014). Hence, irrigation water used by the farm qualified or classified as 'safe' for irrigation purpose with close monitoring of the $\mathrm{Na}$ level to prevent the occurrence of sodicity in the farm due to inappropriate use of irrigation water. In general, the quality of irrigation water needs to be determined 
periodically through laboratory analysis in order to maintain a safe salt balance in the soil (Brady and Weil, 2002) and to manage safe irrigation practices.

\section{CONCLUSION}

The soils of Ziway Prison farm is characterized by loam surface soil texture with an optimum pore space and BD. The results of $\mathrm{pH}(8.19$ to 8.75$)$, EC $\left(0.28\right.$ to $\left.0.99 \mathrm{dS} \mathrm{m}^{-1}\right)$ and ESP $(2.3$ to $5.3 \%)$ revealed that the farm soil was non-saline non-sodic strongly alkaline condition.Total $\mathrm{N}$ contents of the farm soils ( 0.109 to $0.202 \%)$ were at moderate to high status, whereas OM contents $(1.570$ to $2.490 \%$ ) were at low status. The contents of available P (4.6 to $\left.16.9 \mathrm{mg} \mathrm{kg}^{-1}\right)$ and CEC (15.0 to 29.8 meq $100 \mathrm{~g}^{-1}$ ) were in the range of medium to high. Exchangeable $\mathrm{Ca}, \mathrm{Mg}, \mathrm{K}$ and, extractable $\mathrm{Fe}$ and $\mathrm{Mn}$ values were at high status. Whereas, extractable $\mathrm{Cu}$ and $\mathrm{Zn}$ contents of the farm soils were at marginal and low status, respectively. Moreover, the results of irrigation water $\mathrm{pH}$ ( 7.67) was at normal status and EC was below $0.75 \mathrm{dS} \mathrm{m}^{-1}$, indicating that irrigation water used for the farm qualified as 'safe' for irrigation purpose.

\section{RECOMMENDATIONS}

The major soil fertility constraints observed by all farm Blocks include low in OM and Zn. While, some farm Blocks had medium status in total $\mathrm{N}$, available $\mathrm{P}, \mathrm{CEC}$ and extractable $\mathrm{Cu}$. The results suggest that the need for OM amendment and application of $\mathrm{Zn}$ fertilizer. For an optimum crop production, use of $\mathrm{P}$ and $\mathrm{N}$ fertilizers is also recommended for the farm Blocks that had medium total $\mathrm{N}$ status and available $\mathrm{P}$ status less than the critical level $\left(<8 \mathrm{mg} \mathrm{kg}^{-1}\right)$. Moreover, to increase the $\mathrm{OM}$ and total $\mathrm{N}$ contents of the soils, legume crops should be cultivated frequently by either intercropping or in rotation system. The irrigation water used by the farm contains high Na content and, thus, soil sodicity problem might be a potential in the long run. Thus, to prevent the occurrence of sodicity and sustain productivity of the soil, the $\mathrm{Na}$ imbalance in irrigation water should be periodically monitored and appropriate irrigation method need to be used by the farm.

\section{REFERENCES}

[1] Al-Ghobari H.M. (2011). Effect of Irrigation Water Quality on Soil Salinity and Application Uniformity under Center Pivot Systems in Arid Region. Aust. J. Basic Appl. Sci., 5:72-80.

[2] Ayers R.S.and Westcot D.W. (1994). Water Quality for Agriculture, Irrigation and Drainage Paper 29, rev.1, Food and Agriculture Organization of United Nations, Rome. In: Bauder T.A., R.M. Waskom, P.L. Sutherland and J.G. Davis, 2014. Irrigation Water Quality Criteria. Colorado State University, USA. Irrigation Paper of fact sheetNo. 0.506, 4p.

[3] Bauder T.A., Waskom R.M., Sutherland P.L. and Davis J.G. (2014). Irrigation Water Quality Criteria. Colorado State University, USA. Irrigation Paper of fact sheet No. 0.506, 4p.

[4] Blake C.A. (1965). Methods of Soil Analysis. Part I, American Society of Agronomy. Madison, Wisconsin, USA. 1572p.

[5] Bohn, H., McNeal, B. and G. Connor, 2001. Soil Chemistry. $3^{\text {rd }}$ ed. John Willey and Sons, New York, USA.

[6] Bouyoucos G.J. (1962). Hydrometer Method Improvement for Making Particle Size Analysis of Soils. Agron. J., 54: 179-186.

[7] Brady N.C. and Weil R.R. (2002). The Nature and Properties of Soils, $13^{\text {th }}$ ed. Prentice- Hall Inc., New Jersey, USA. 960p.

[8] FAO (Food and Agricultural Organization). (1979). Soil Survey Investigation for Irrigation, Soil Bulletin 42. FAO, Rome, Italy.

[9] FAO (Food and Agricultural Organization). (2006). Guidelines for soil description. $4^{\text {th }}$ ed., Food and Agricultural Organizationof the United Nations, Rome.

[10] FAO (Food and Agricultural Organization). (2006a). Scaling Soil Nutrient Balances. Fertilizer and Plant Nutrition, Bulletin No. 15. FAO, Rome, Italy.

[11] Finck A. and Vendateswarlu J. (1982). Chemical Properties and Fertility Management of Vertisols. In: Vertisols and Rice Soils of the Tropics. Symposium Papers 2. Transaction of the $12^{\text {th }}$ International Congress of Soil Science, New Delhi, India, 3: 61-69.

[12] Franson H.N. (1981). Standard Methods for the Examination of Water and Waste Water. $15^{\text {th }}$ ed., APHAAWWA-WPCF, USA. 
[13] Gupta P.K. (2004). Soil, Plant, Water and Fertilizer Analysis. Shyam Printing Press, Agrobios, India. 438p.

[14] Hurni H. and Bruno M. (1990). Degradation and Conservation of the Soil Resources in the Ethiopian Highlands. African Mountains and Highlands: Problems and Perspectives, USA, pp. 51-64.

[15] Jones J.B. (2003). Agronomic Handbook: Management of Crops, Soils, and Their Fertility. CRC Press LLC, Boca Raton, FL, USA. 482p.

[16] Landon J.R.(1991). Booker Tropical Soil Manual: A Handbook for Soil Survey and Agricultural Land Evaluation in the Tropics and Subtropics. Longman Scientific and Technical, Essex, New York. 474p.

[17] MesfinAbebe. (1996). The Challenges and Future Prospects of Soil Chemistry in Ethiopia. pp. 7896.

[18] Motavalli, P. and McConnell J. (1998). Land Use and Soil Nitrogen Status in a Tropical Pacific Island Environment. Journal of environmental quality, 27: 119-123.

[19] Muhammad W., Vaughan S.M., DalalR.C. And. Menzies N.W. (2011). Crop Residues and Fertilizer Nitrogen Influence Residue Decomposition and Nitrous Oxide Emission from a Vertisol. Biology and Fertility of Soil, 47: 15 - 23.

[20] Musefa Redi, WubayehuGebremedhin, FitsumMerkeb and Mohamed Yimam.(2016). Critical Level of Extractable Phosphorus for Maize (Zea mays L.) at Metekel Zone, Northwestern Ethiopia. World scientific news, 54: 14-26.

[21] Nnadi L.A. and Haque I. (1988). Forage Legumes in Africa Crop-livestock Production Systems. ILCA Bulletin 30, 10-17.

[22] OESPO (Oromia Economic Study Project Office).(2003). Regional Government of Oromia; Oromia Economic Study Project Office. AdamiTullu-JidoKombolchaWoreda Based Development Programme.

[23] Olsen S.R., Cole C.V., WatanableF.S. And Dean L.A. (1954). Estimation of Available Phosphorus in Soil by Extraction with Sodium bi-carbonate. USDA Circular, 939: 1-19.

[24] Rowell D.L. (1994). Soil Science: Methods and Applications. Addison Wesley Longman Singapore Publishers (Pte) Ltd., England, UK. 350p.

[25] SahlemedhinSertsu and TayeBekele. (2000). Procedures for Soil and Plant Analysis. National Soil Research Organization, Ethiopian Agricultural Research Organization, Addis Ababa.110p.

[26] Silva J.A. and Uchida R. (2000). Plant Nutrient Management in Hawaii's Soils, Approaches for Tropical and Subtropical Agriculture, College of Tropical Agriculture and Human Resources, University of Hawaii, Manoa.

[27] Sims J.T. and Johnson C.V. (1991). Micronutrient Soil Tests. In: Mortvedt J.J., Cox F.R., Shuman L.M., Welch R.M. (eds): Micronutrients in Agriculture. Book series No. 4. Madison, Soil Science Society of America, 427-476.

[28] Singh B.V.K, Sharma B.B. and Dwivedi B.S. (2002). The Impact of Diversification of a Rice-wheat Cropping System on Crop Productivity and Soil Fertility. J. Agric. Sci., 139: 405-412

[29] Taylor M.D., Kim N.D., Hill R.B. and Chapman R.(2010). A Review of Soil Quality Indicators and Five Key Issues after 12 years Soil Quality Monitoring in the Waikato Region. British Society of Soil Science, Soil Use and Management, 26: 212-224.

[30] TekalignMamo and Haque I. (1991). Phosphorous Status of Some Ethiopian soils.III. Evaluation of Soil Test Methods for Available Phosphorus. Trop. Agr., 61-66.

[31] TekalignTadese. (1991). Soil, Plant, Water, Fertilizer, Animal Manure and Compost Analysis. Working Document No. 13. International Livestock Research Center for Africa, Addis Ababa, Ethiopia.

[32] Tesfahunegn G.B., Tamene L. and Vlek P.L.G. (2011). Catchment-scale Spatial Variability of Soil Properties and Implications on Site-specific Soil Management in Northern Ethiopia. Soil and Tillage Research, 117: 124-139.

[33] Van Reeuwijk L.P. (1992). Procedures for Soil Analysis, $3^{\text {rd }}$ edition. International Soil Reference and Information Center (ISRIC), Wageningen, the Netherlands, 34p.

[34] WakeneNegassa and HelufGebrekidan. (2003). Forms of Phosphorus and Status of Available Micronutrients under Different Land-use Systems of Alfisols in Bako Area of Ethiopia. Ethiopian Journal of Natural Resources, 5(1): 17-37.

[35] Walkley A. and Black I.A.(1934). An Examination of Different Methods for Determining Soil Organic Matter and the Proposed Modification by the Chromic Acid Titration Method. Soil Sci., 37: 29-38.

[36] WondwosenTene and ShelemeBeyene. (2011). Identification of Growth Limiting Nutrient(s) in Alfisols: Soil Physico-chemical Properties, Nutrient Concentration and Biomass Yield of Maize. American Journal of plant nutrient and fertilizer technology, 1(1): 23-35. 
Soil Fertility and Irrigation Water Characterization of Ziway prison Farm at East Shewa Zone of Oromiya, Ethiopia

[37] YihenewGebreselssie. (2002). Selected Chemical and Physical Characteristics of Soils of Adet Research Center and its Testing Sites in Northwestern Ethiopian. Society of Soil Science. Ethiopian J, Natura. Resource, 4: 199-215.

[38] Zhang J.H., Li Y., Lindstrom M.J. and Yang Z. (2000). Soil Water Properties in a Recently Established Forest as Affected by Grazing in a Semiarid Valley. Soil Use and Management, 16: 234235.

Citation: Musefa Redi, Israel Bekele, "Soil Fertility and Irrigation Water Characterization of Ziway prison Farm at East Shewa Zone of Oromiya, Ethiopia” International Journal of Research Studies in Agricultural Sciences (IJRSAS), 2019; 5(4), pp. 44-53, http://dx.doi.org/10.20431/2454-6224.0504005

Copyright: (C) 2019 Authors. This is an open-access article distributed under the terms of the Creative Commons Attribution License, which permits unrestricted use, distribution, and reproduction in any medium, provided the original author and source are credited. 